\title{
PENGARUH STRUKTUR MODAL, UKURAN PERUSAHAAN, PERTUMBUHAN PERUSAHAAN TERHADAP KINERJA KEUANGAN PADA PERUSAHAAN NON KEUANGAN DENGAN MENGGUNAKAN DUPONT SYSTEM
}

\author{
Ingrid Brigita Jonatan \\ Fakultas MagisterEkonomi Universitas Tarumanagara \\ Jakarta \\ Email: ingreat_light@yahoo.com
}

\begin{abstract}
The purpose of this study is to determine the effect of capital structure, firm size, and company growth on financial performance using the dupont system. In this study, the method used is quantitative method using the Eviews 8 software. The result of research conducted on 167 non-financial companies shows that financial performance is influenced by the capital structure and firm size, while company growth does not affect financial performance. The end result of this study does not yet have a strong conclusion that the growth of companies in Indonesia has an influence on company performance. The resulting $R$-square is considered small.
\end{abstract}

Keywords: Financial Performance, Capital Structure, Firm Size, Company Growth, Dupont System

\begin{abstract}
ABSTRAK
Tujuan Penelitian ini yaitu untuk mengetahui Pengaruh Struktur modal, Ukuran perusahaan, Pertumbuhan perusahaan terhadap Kinerja keuangan dengan menggunakan dupont system. Didalam penelitian ini metode yang digunakan adalah metode kuantitatif menggunakan program Eviews 8. Dari hasil penelitian yang telah dilakukan pada 167 perusahaan non keuangan menunjukan bahwa kinerja keuangan dipengaruhi oleh struktur modal dan ukuran perusahaan. Sedangkan Pertumbuhan perusahaan tidak mempengaruhi Kinerja keuangan. Hasil akhir dari penelitian ini belum memiliki kesimpulan yang kuat bahwa pertumbuhan perusahaan di Indonesia memiliki pengaruh terhadap kinerja perusahaan. $R$-square yang dihasilkan masih tergolong kecil.
\end{abstract}

Kata kunci: Kinerja Keuangan, Struktur modal, Ukuran perusahaan, Pertumbuhan perusahaan

\section{PENDAHULUAN}

\section{Latar Belakang}

Tujuan mendirikan suatu perusahaan antara lain ialah memaksimalkan profit, mempertahankan kelangsungan hidup perusahaan, dan memaksimalkan kesejahteraan pemegang saham. Tujuan perusahaan tersebut akan tercapai jika di dalam perusahaan terdapat manajemen perusahaan yang bermutu tinggi. Manajemen yang bermutu tinggi tersebut akan terlihat pada kemampuan mereka dalam mengelola sumber daya yang dimiliki perusahaan dan menjalankan operasional perusahaan dengan baik. Maka dari itu, setiap perusahaan dituntut untuk dapat tetap bertahan dalam iklim persaingan yang semakin kompetitif. Hal ini mendorong perusahaan untuk semakin meningkatkan kinerja keuangannya agar dapat tetap bertahan dan dapat berinovasi dengan lingkungan global maka perusahaan harus memiliki strategi dan manajemen yang tepat serta handal agar dapat menyiasati ketatnya persaingan tersebut sehingga dapat bersaing dengan sehat dan kritis.

F. Donaldson Brown menciptakan Dupont System ketika melakukan analisis keuangan General Motors. Analisis Du Pont System mengukur tingkat efisiensi perusahaan serta tingkat keuntungan penjualan produk perusahaan. Analisis Du Pont digunakan untuk mengetahui faktor mana yang paling kuat pengaruhnya antara profit margin dan total asset turnover terhadap ROI. Analisis Dupont dapat mengukur pengendalian biaya dan efisiensi perputaran aktiva yang terjadi yang disebabkan oleh fliktuasi penjualan 


\section{Kajian Teori}

Kinerja Keuangan Perusahaan Menurut Aliminsyah dan Padji (2006) kinerja keuangan perusahaan adalah suatu istilah umum yang digunakan untuk sebagian atau seluruh tindakan atau aktivitas dan suatu organisasi pada suatu periode, seiring dengan referensi pada sejumlah standar seperti biaya-biaya masa lalu atau yang diproyeksikan, suatu dasar efisiensi, pertanggungjawaban, atau akuntabilitas manajemen. Kinerja keuangan perusahaan adalah suatu tampilan tentang kondisi keuangan perusahaan selama periode tertentu. Untuk mengukur keberhasilan suatu perusahaan pada umumnya berfokuspada laporan keuangannya, disamping data-data non keuangan lain yang bersifat sebagai penunjang. Informasi kinerja bermanfaat untuk memprediksi kapasitas perusahaan dalam menghasilkan arus kas dan sumber dana yang ada.

Menurut Syamsudin (2001) analisis Du Pont System yaitu Return On Invesment (ROI) yang dihasilkan melalui perkalian antara keuntungan dari komponen sales serta efisiensi penggunaan total assets dalam menghasilkan keuntungan tersebut.

Menurut Sutrisno (2003) analisis Du Pont System adalah analisis yang digunakan untuk dapat mengontrol perubahan dalam rasio aktivitas, net profit margin dan seberapa besar pengaruhnya terhadap Return On Invesment (ROI).

Analisis Du Pont menggabungkan rasio-rasio aktivitas dan net profit margin, dan menunjukkan bagaimana rasio tersebut berinteraksi untuk dapat menentukan profitabilitas aktiva-aktiva yang dimiliki oleh perusahaan. Jika rasio perputaran dikalikan dengan marjin laba penjualan, hasilnya adalah tingkat pengembalian aktiva (ROA) atau sering disebut juga tingkat pengembalian investasi (ROI) (Sawir, 2005)

Sistem $D u$ Pont sendiri sering digunakan untuk pengendalian antar divisi, prosesnya disebut dengan pengendalian terhadap tingkat pengembalian investasi (ROI). Jika ROI untuk divisi tertentu berada di bawah angka yang ditargetkan, melalui sistem DuPont dapat ditelusuri penyebab terjadinya penurunan ROI.

Faktor-Faktor Internal yang Mempengaruhi Kinerja Keuangan:

\section{a. Struktur Modal}

Perusahaan mendahulukan pembayaran pokok hutang beserta bunga terlebih dahulu daripada kepentingan investor karena kreditur memiliki posisi yang lebih tinggi daripada pemegang saham. Sehingga investor akan berhati-hati untuk investasi di perusahaan yang memiliki leverage yang tinggi karena semakin tinggi rasio leverage, maka semakin tinggi tingkat risiko investasinya. Tingkat hutang yang semakin tinggi ini menyebabkan penurunan kinerja keuangan. Hal ini dikarenakan perusahaan berfokus dalam meningkatkan produktivitas untuk melunasi hutang tersebut (Lazar, 2016).

b. Ukuran Perusahaan

Menurut calisir et al (2010) Ukuran perusahaan dapat berpengaruh secara positif terhadap kinerja keuangan. Menurut utami (2012) dan penelitian mirza, javed (2013) Pertumbuhan berpengaruh positif terhadap kinerja keuangan. Sedangkan menurut Lazar (2016) ukuran perusahaan berpengaruh negatif terhadap kinerja keuangan.

c. Pertumbuhan

Perusahaan yang memiliki kesempatan untuk bertumbuh yang tinggi secara umum menunjukkan bahwa perusahaan tersebut memiliki kinerja perusahaan yang baik. Menurut 
Kerangka pemikiran dalam penelitian ini seperti digambarkan dibawah ini: Gambar 1.

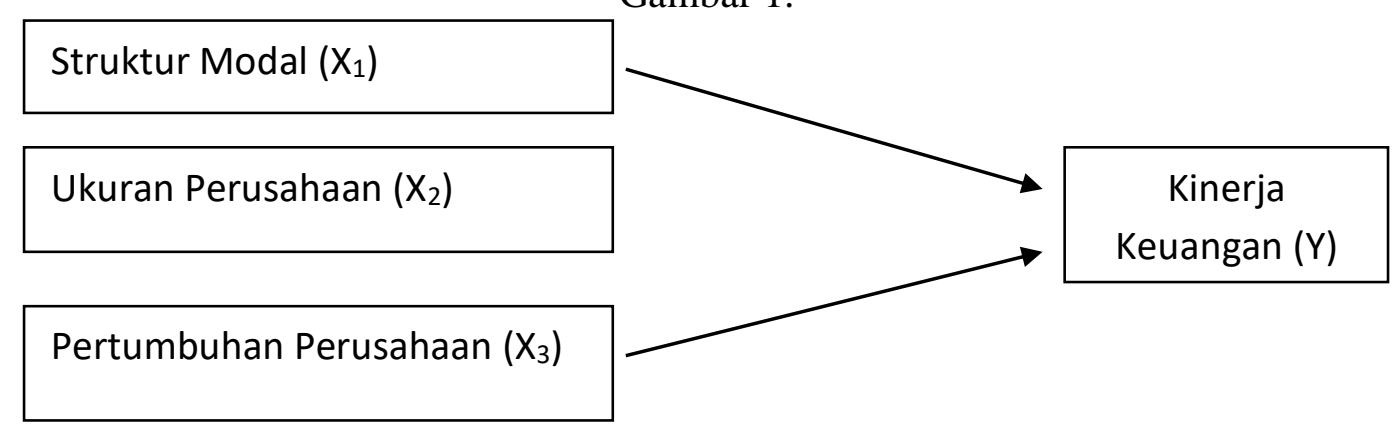

Kerangka PemikiranHipotesis dari model yang dibangun di atas adalah sebagai berikut:

$\mathrm{H}_{1}=$ Struktur Modal berpengaruh negatif terhadap Kinerja Keuangan

$\mathrm{H}_{2}=$ Ukuran Perusahaan berpengaruh positif terhadap Kinerja Keuangan

$\mathrm{H}_{3}=$ pertumbuhan berpengaruh positif terhadap Kinerja Keuangan

\section{METODE PENELITIAN}

Penelitian ini termasuk ke dalam penelitian deskriptif. Objek penelitian dalam penelitian ini terdiri dari variabel independen, dan variabel dependen. Objek penelitian dalam penelitian ini adalah Struktur Modal, Ukuran perusahaan, pertumbuhan perusahaan dan kinerja keuangan sebagai variabel dependen. Variabel independen merupakan variabel stimulus yang mempengaruhi variabel lain. Variabel independen merupakan variabel yang bisa diukur, dimanipulasi, atau dipilih oleh peneliti untuk menentukan hubungannya dengan suatu gejala yang diobservasi (Sarwono, 2014). Variabel dependen adalah variabel yang diamati dan diukur untuk menentukan pengaruh yang disebabkan oleh variabel terikat (Sarwono, 2014). Unit analisis pada penelitian ini adalah perusahaan non keuangan yang terdaftar di Bursa Efek Indonesia pada tahun 2012-2016.

Penelitian ini menggunakan eviews versi 8 dengan Uji Statistik Deskriptif untuk menguji data sampel. Untuk uji hipotesis, penelitian ini menggunakan Robust least Square $\left(\mathrm{R}^{2}\right)$, dan Uji hipotesis parsial.

\section{HASIL DAN PEMBAHASAN}

Tabel 4.2

statistik Deskriptif Tahun 2012-2016

\begin{tabular}{lrrrr}
\hline \hline & \multicolumn{1}{c}{ ROI } & LEV & \multicolumn{1}{c}{ SIZE } & GROWTH \\
\hline \hline Mean & -35.76424 & 0.567459 & 6.325066 & 1.455896 \\
Median & 0.053834 & 0.458142 & 6.346374 & 0.069260 \\
Maximum & 686.0756 & 11.84432 & 8.254333 & 199.6375 \\
Minimum & -12956.15 & 0.007416 & 3.705949 & -1.000000 \\
Std. Dev. & 537.3734 & 0.788923 & 0.740499 & 10.95530 \\
Skewness & -19.27100 & 9.247622 & -0.226798 & 12.57570 \\
Kurtosis & 424.4998 & 105.4171 & 3.247406 & 186.5559 \\
Jarque-Bera & 6232842. & 376840.4 & 9.287962 & 1194237. \\
Probability & 0.000000 & 0.000000 & 0.009619 & 0.000000 \\
Sum & -29863.14 & 473.8282 & 5281.430 & 1215.673 \\
Sum Sq. & $2.41 E+08$ & 519.0811 & 457.3147 & 100095.5
\end{tabular}


Dev.

Observatio ns

Sumber: Diolah sendiri oleh Penulis denggan menggunakan Eviews 8

Tabel 4.2 menggambarkan karakteristik antara variable-variabel yang diteliti. Total sampel yang diteliti adalah sebanyak 835 sampel yang terdiri dari 167 perusahaan non keuangan yang terdaftar di Bursa Efek Indonesia dari tahun 2012-2016 yang memiliki laporan keuangan lengkap.

Objek penelitian ini adalah struktur modal (Leverage $\left.=\mathrm{X}_{1}\right)$, ukuran perusahaan $\left(\right.$ Size $\left.=\mathrm{X}_{2}\right)$, pertumbuhan perusahaan $\left(\right.$ Growth $\left.=\mathrm{X}_{3}\right)$. Dalam penelitian ini variabel yang digunakan adalah kinerja keuangan sebagai variabel dependen, dan variabel independen adalah struktur modal, ukuran perusahaan, Pertumbuhan perusahaan.

Uraian mengenai objek penelitian dapat dilihat dalam statistik deskriptif yang diolah menggunakan Eviews 8. Analisis ini bertujuan untuk menjelaskan nilai rata-rata (mean), maksimum, minimum, dan standar deviasi untuk masing-masing variabel penelitian.

Berdasarkan Tabel 4.2 di atas, menggambarkan bahwa nilai rata-rata (mean) struktur modal (Leverage $=\mathrm{X}_{1}$ ) dari sampel yang diteliti adalah sebesar 0.567459. Sedangkan untuk nilai tengah sebesar 0.458142 . Nilai maksimum struktur modal adalah 11.84432 yang merupakan milik dari Rimo Internastional Lestari Tbk pada tahun 2013, sedangkan nilai minimum struktur modal adalah sebesar 0.007416yang merupakan milik dari Cakra Mineral Tbk pada tahun 2013. Besarnya standar deviasi atau penyimpangan yang terjadi pada struktur modal sebesar 0.788923 .

Nilai rata-rata (mean) ukuran perusahaan $\left(\right.$ Size $\left.=\mathrm{X}_{2}\right)$ dari sampel yang diteliti adalah sebesar 6.325066. Sedangkan untuk nilai tengah sebesar 6.346374. Nilai maksimum ukuran perusahaan adalah 8.254333 yang merupakan milik dari Telekomunikasi Indonesia (persero)Tbk pada tahun 2016, sedangkan nilai minimum ukuran perusahaan adalah sebesar 3.705949 yang merupakan milik dari Rimo Internastional Lestari Tbkpada tahun 2013. Besarnya standar deviasi atau penyimpangan yang terjadi pada ukuran perusahan 0.740499 .

Nilai rata-rata (mean) Pertumbuhan Perusahaan $\left(\right.$ Growth $\left.=\mathrm{X}_{3}\right)$ dari sampel yang diteliti adalah sebesar 1.455896. Sedangkan untuk nilai tengah sebesar 0.069260. Nilai maksimum pertumbuhan perusahaan adalah 199.6375 yang merupakan milik dari Samindo Resources Tbk pada tahun 2016, sedangkan nilai minimum pertumbuhan perusahaan adalah sebesar -1.000000 yang merupakan milik dari Pioneerindo Gourmet International Tbk pada tahun 2016. Besarnya standar deviasi atau penyimpangan yang terjadi pada Pertumbuhan perusahaan 10.95530.

Nilai rata-rata (mean) Kinerja Keuangan (Return on investment=Y) dari sampel yang diteliti adalah sebesar -35.76424. Sedangkan untuk nilai tengah sebesar 0.053834. Nilai maksimum Kinerja Perusahaan adalah 686.0756 yang merupakan milik dari Bumi Resources Tbk pada tahun 2016, sedangkan nilai minimum kinerja keuangan adalah sebesar -12956.15 yang merupakan milik dari Rimo Internastional Lestari Tbk pada tahun 2015. Besarnya standar deviasi atau penyimpangan yang terjadi pada kinerja keuangan sebesar 537.3734.

Berdasarkan Tabel 4.2 diatas, Nilai total (SUM) untuk variabel ROI (Y) sebesar 29863.14, Leverage $\left(\mathrm{X}_{1)}\right.$ sebesar 473.8282, Size $\left(\mathrm{X}_{2}\right)$ sebesar 5281.430 dan Growth $\left(\mathrm{X}_{3}\right)$ sebesar 1215.673. 


\section{Hasil pengujian dengan Robust Least Square}

Dependent Variable: ROI

Method: Robust Least Squares

Date: 01/08/18 Time: 17:12

Sample: 20122016

Included observations: 835

Method: S-estimation

S settings: tuning $=1.547645$, breakdown $=0.5$, trials $=200$, subsmpl $=4$, refine $=2$, compare $=5$

Random number generator: $\mathrm{rng}=\mathrm{kn}$, seed $=1961962013$

Huber Type I Standard Errors \& Covariance

\begin{tabular}{|c|c|c|c|c|}
\hline Variable & Coefficient & Std. Error & z-Statistic & Prob. \\
\hline LEV & -0.105224 & 0.004064 & -25.89470 & 0.0000 \\
\hline SIZE & 0.025201 & 0.004362 & 5.777703 & 0.0000 \\
\hline GROWTH & 0.000235 & 0.000284 & 0.826053 & 0.4088 \\
\hline $\mathrm{C}$ & -0.055252 & 0.028516 & -1.937547 & 0.0527 \\
\hline \multicolumn{5}{|c|}{ Robust Statistics } \\
\hline R-squared & 0.053555 & \multirow{3}{*}{\multicolumn{2}{|c|}{$\begin{array}{l}\text { Adjusted R-squared } \\
\text { Deviance } \\
\text { Prob (Rn-squared stat.) }\end{array}$}} & 0.050138 \\
\hline Scale & 0.158953 & & & 0.025266 \\
\hline \multirow[t]{2}{*}{ Rn-squared statistic } & 849.3480 & & & 0.000000 \\
\hline & \multicolumn{3}{|c|}{ Non-robust Statistics } & \\
\hline Mean dependent var & -35.76424 & S.D. dependent var & & 537.3734 \\
\hline S.E. of regression & 539.5213 & Sum squared resid & & $2.42 \mathrm{E}+08$ \\
\hline
\end{tabular}

Pengujian hipotesis ini digunakan untuk menguji pengaruh variabel Struktur Modal, Ukuran Perusahaan, pertumbuhan perusahaan terhadap Kinerja Keuangan dengan menggunakan Dupont System.

\section{Hipotesis 1: Struktur Modal berpengaruh negatif terhadap Kinerja Keuangan}

Dengan kriteria untuk pengujian hipotesis sebagai berikut:

Jika probabilitas hitung $<0,05$; maka $\mathrm{H}_{1}$ diterima.

Jika probabilitas hitung $>0,05$; maka $\mathrm{H}_{1}$ ditolak.

Dari hasil perhitungan diperoleh nilai probabilitas pada kolom Prob. Sebesar 0,0000 $<0,05$, sehingga dapat disimpulkan bahwa Struktur Modal berpengaruh secara signifikan terhadap Kinerja Keuangan. Koefisien regresi untuk variabel struktur modal adalah negatif sebesar -0.105224 . Hal ini berarti jika struktur modal bertambah $1 \%$ maka kinerja keuangan akan berkurang sebesar 10,5224\% dengan asumsi variabel independen adalah konstan. Koefisien regresi bernilai negatif menunjukkan bahwa struktur modal berpengaruh negatif terhadap kinerja keuangan, artinya semakin tinggi struktur modal maka kinerja keuangan akan semakin kecil. Hasil dari penelitian ini sesuai dengan teori trade-off yang menyebutkan bahwa Penggunaan hutang dapat meningkatkan nilai perusahaan sampai batas leverage yang optimal, dan sesudahnya penggunaan hutang 
tersebut akan menurunkan nilai perusahaan, karena penggunaan hutang setelah leverage yang optimal akan menimbulkan suatu biaya kebangkrutan yang lebih besar.

\section{Hipotesis 2: Ukuran Perusahaan berpengaruh positif terhadap Kinerja Keuangan}

Dengan kriteria untuk pengujian hipotesis sebagai berikut:

Jika probabilitass hitung <0,05; maka $\mathrm{H}_{2}$ diterima.

Jika probabilitas hitung $>0,05$; maka $\mathrm{H}_{2}$ ditolak.

Dari hasil perhitungan diperoleh nilai probabilitas pada kolom Prob. Sebesar 0,0000 < 0,05, maka dapat disimpulkan bahwa Ukuran Perusahaan berpengaruh secara signifikan terhadap Kinerja Keuangan. Koefisien regresi untuk variabel ukuran perusahaan adalah positif sebesar 0.025201 . Hal ini berarti jika ukuran perusahaan bertambah $1 \%$ maka kinerja keuangan akan bertambah sebesar $25,201 \%$ dengan asumsi variabel independen adalah konstan. Koefisien regresi bernilai positif menunjukkan bahwa ukuran perusahaan berpengaruh positif terhadap kinerja keuangan, artinya semakin tinggi ukuran perusahaan maka kinerja keuangan akan semakin besar. Hasil ini menunjukkan bahwa ukuran perusahaan sesuai dengan teori trade-off yaiyu Semakin besar suatu perusahaan maka semakin stabil pula pendapatan yang akan diperoleh perusahaan, sehingga suatu perusahaan yang besar akan memiliki pengaruh terhadap kinerja keuangan perusahaannya dibandingkan dengan perusahaan yang kecil.

\section{Hipotesis 3: = Pertumbuhan perusahaan berpengaruh positif terhadap Kinerja Keuangan}

Dengan kriteria untuk pengujian hipotesis sebagai berikut:

Jika probabilitass hitung <0,05; maka $\mathrm{H}_{3}$ diterima.

Jika probabilitas hitung $>0,05$; maka $\mathrm{H}_{3}$ ditolak.

Dari hasil perhitungan diperoleh nilai probabilitas pada kolom Prob. Sebesar 0,4088 > 0,05, maka keputusan Ho diterima dan Ha ditolak. Koefisien regresi untuk variabel Pertumbuhan perusahaan adalah negatif sebesar 0.000235 . Hal ini berarti jika likuiditas bertambah $1 \%$ maka kinerja keuangan akan berkurang sebesar $0,0235 \%$ dengan asumsi variabel independen adalah konstan. Koefisien regresi bernilai positif menunjukkan bahwa pertumbuhan perusahaan berpengaruh positif terhadap kinerja keuangan, artinya semakin tinggi pertumbuhan perusahaan maka kinerja keuangan akan semakin besar korelasi ini menunjukan bahwa perusahaan yang sedang bertumbuh akan memperhatikan kinerja keuangannya. Hasil ini menunjukkan bahwa ukuran perusahaan sesuai dengan signaling theory dengan harapan bahwa kinerja suatu perusahaan dapat memberikan signal positif terhadap perusahaan. Signal ini dapat membawa para pelaku bursa untuk melakukan investasi melalui pembelian saham suatu perusahaan dan sesuai juga dengan Pecking order theory yang mengasumsikan bahwa perusahaan bertujuan untuk memaksimukan kesejahteraan para pemegang saham hal ini dapat dilihat dari pertumbuhan perusahaan.

\section{Diskusi}

Hasil pengujian statistik dengan uji parsial menunjukkan bahwa variabel Pertumbuhan perusahaan tidak memiliki pengaruh yang signifikan terhadap Kinerja Keuangan. Hasil pengujian Hipotesis dengan uji Robust least Square menunjukkan bahwa variabel Pertumbuhan tidak memiliki pengaruh yang signifikan terhadap Kinerja Keuangan. 


\section{KESIMPULAN DAN SARAN}

Berdasarkan hasil pengujian data dalam penelitian ini, menunjukan bahwa kinerja keuangan dipengaruhi oleh struktur modal dan ukuran perusahaan.

Keterbatasan dari penelitian ini antara lain: (1) Perusahaan yang digunakan dalam penelitian hanya perusahaan jasa sub sektor properti, real estate, dan konstruksi bangunan, (2) Jumlah variabel independen yang digunakan hanya terbatas pada empat variabel, yaitu rasio likuiditas, rasio solvabilitas, rasio aktivitas, dan rasio profitabilitas, (3) Penelitian yang hanya berfokus pada periode 2013-2016.

Berdasarkan hasil dan keterbatasan di atas, maka saran yang dapat diberikan untuk penelitian selanjutnya, antara lain:

1. Pada penelitian ini periode pengamatan yang digunakan hanya lima tahun, yaitu dari tahun 2012-2016

2. Pada penelitian ini hanya dilakukan sebatas variabel struktur modal, ukuran perusahaan, pertumbuhan perusahaan.

3. Keterbatasan waktu, akses data yang mengakibatkan data yang diperoleh hanya 5 tahun.

4. Cakupan penelitian pada penelitian ini hanya pada perusahaan non keuangan yang terdaftar di Bursa Efek Indonesia, sehingga untuk penulis selanjutnya masih terbuka kesempatan untuk memperluas cakupan penelitian.

\section{REFERENSI}

Anugrahani, Evida. 2007. Analisis Du Pont System Dalam Mengukur Kinerja Keuangan Perusahaan (Studi Pada PT. Aqua Golden Missisipi Tbk, PT. Mayora Indah Tbk, PT. Ultra Jaya Milk Tbk). Jurusan Manajemen. Fakultas Ekonomi. Universitas Muhammadiyah Malang.

Azizah, Kertahadi, dan Fransisca. 2015. Analisis Kinerja Keuangan Perusahaan (Perbandingan Penggunaan Analisis Rasio Keuangan dan Du Pont System) Studi Pada PT. Unilever Indonesia, Tbk dan Anak Perusahaan yang Terdaftar di BEI Periode 2007-2013. Jurnal Administrasi Bisnis (JAB), Volume 25 No.2. Universitas Brawijaya.

Calisir, Fethi, Cigdem Altin Gumussoy, A. Elvan Bayraktaroglu, and Ece Deniz. 2010. "Intellectual Capital in the Quoted Turkish ITC Sector", Journal of Intellectual Capital, Vol.II(4), page 537-553.

Darsono dan Ashari. 2005. Pedoman Praktis Memahami Laporan Keuangan, Edisi Pertama, Andi, Yogyakarta.

Darmawan, Yanu. 2009. Analisis Du Pont System untuk Menilai Kinerja Keuangan Perusahaan. Universitas Muhammadiyah Surakarta: JournalAccounting

Daulat, Freddy dan Hildawati. 2014. Analisis Kinerja Keuangan Perusahaan Dengan Menggunakan Metode Du Pont System (Studi Pada Perusahaan Food and Beverage yang Terdaftar di BEI Periode Tahun 2008-2010). Jurnal Ilmiah, Volume 11 No 2. Universitas Esa Unggul Jakarta.

Dermawan, S dan Djahotman, P. 2011. Analisis Laporan Keuangan Cara Mudah dan Praktis Memahami Laporan Keuangan. Edisi Pertama. Jakarta: Mitra Wacana Media.

Evans, David S., J uni 1987, The Relationship Between FirmGrowth, Size and Age: Estimater for 100 Manufacturing Industries, The Journal of Industrial Economics: The empirical Renaissance in Industrial Economics, Vol. 35, No.4, p. 568 
PENGARUH STRUKTUR MODAL, UKURAN PERUSAHAAN,

Ingrid Brigita Jonatan

PERTUMBUHAN PERUSAHAAN TERHADAP KINERJA

KEUANGAN PADA PERUSAHAAN NON KEUANGAN DENGAN

MENGGUNAKAN DUPONT SYSTEM

Hanafi, Mamduh dan Halim, Abdul. 2007. Analisis Laporan Keuangan, Edisi Ketiga. Cetakan Pertama. Penerbit UPP Sekolah Tinggi Ilmu Manajemen YKPN, Yogyakarta.

IAI, 2002. Standar Akuntansi Keuangan. Jakarta: Salemba Empat.

IAI, 2004. Standar Akuntansi Keuangan. Jakarta: Salemba Empat.

Kasmir, 2009. Analisis Laporan Keuangan. Jakarta: PT. Raja Grafindo Persada.

Kasmir, 2011. Analisis Laporan Keuangan. Cetakan 4. Jakarta: PT. Raja Grafindo Persada.

Kathryn J. Chang, Doina C. Chichernea, Hassan R. HassabElnaby (2013). On the DuPont analysis in the health care industry. J. Account. Public Policy 33 (2014) 83-103

Listiadi. 200 Analisis Keuangan Sistem DuPont Sebagai Alat Pengukur Profitabilitas. Jurnal Ekonomi dan Manajemen Volume 8. Nomor 1. Februari 2007. Universitas Negeri Surabaya.

Martoyo dan Harjito. 2004. Manajemen Keuangan, Edisi Pertama, Cetakan Keempat, Penerbit Ek onisia, Kampus Fakultas UII, Yogyakarta.

Mumtaz, R., Rauf, Shahnaz A., Ahmed, B., Noreen, U. 2013. Capital Structure and Financial Performance: Evidence from Pakistan (Kse 100 Index). Journal of Basic and Applied Scientific Research, 3(4), 113-119.

Munawir, 2001. Analisa Laporan Keuangan, Edisi Keempat, Liberty. Yogyakarta.

Munawir, 2002. Analisis Laporan Keuangan. Yogyakarta: Liberty.

Munawir, 2007. Analisis Laporan Keuangan. Edisi 4. Cetakan 5. Yogyakarta: Liberty.

Prastowo, Dwi. 2002. Analisis Laporan Keuangan. Cetakan Kedua. Yogyakarta: UPP AMP YKPN.

Pratheepkanth, Puwanenthiren. 2011. Capital Structure and Financial Performance: Evidence from Selected Business Companies in Colombo Stock Exchange Sri Lanka. Journal of Arts, Science \& Commerce, (2), 171-183.

Sawir 2005. Analisis Kinerja Keuangan dan Perencanaan Keuangan Perusahaan, Cetakan Kelima, PT. Gramedia Pustaka Utama, Jakarta.

Sofyan Harahap. 2004. Analisis Kritis atas Laporan Keuangan. Cetakan 4. Jakarta: PT. Raja Grafindo Persada.

Sutrisno.2003. Manajemen Keuangan, Teori, Konsep dan Aplikasi, Edisi Pertama, Cetakan Ketiga, Ekonisia, Yogyakarta.

Sundjaja Ridwan S. dan Barlian Inge. 2003. Manajemen Keuangan. Edisi 2. Cetakan 4. Jakarta: Literata Lintas Media.

Syamsuddin, Lukman. 2000 Manajemen Keuangan Perusahaan, Edisi Baru, Cetakan Kelima, Raja Grafindo Persada, Jakarta.

Titik, Widarsih. Analisa Du Pontsystem Sebagai Alat Untuk Mengukur Kinerja Keuangan (Studi Pada PT. Siantar Top, Tbk)

Utami, S. R. (2012). Determinants of Capital Structure of Firms in The Manufacturing Sector of Firms in Indonesia. Maastricht School of Management.

Vasile Burja (2014). The study of factors that may influence the performance by the Dupont analysis in the furniture industry. 21st International Economic Conference 2014, IECS 2014, 16-17 May 2014, Sibiu, Romania

Wuryaningsih dan Moh Dziqron. 2014. Penerapan Du Pont System Untuk Mengukur Kinerja Keuangan Perusahaan (Studi Pada Perusahaan Semen Yang Terdafar di BEI Tahun 2007-2011). Jurnal Ilmiah. Volume 6. No.1. Universitas Muhammadiyah Surakarta. 
Wright, Peter, Mark Kroll, Ananda Mukhreji, Michael L. Pettus. 2009. "Do the Contingencies of External Monitoring, Ownership Incentives, or Free Cash Flow Explain Opposing Firm Performance Expectations?", Journal Management Governance, 13, pp. 215-243.

Yogantara, I. Made., Wijaya, Liliana. 2010. Hubungan Struktur Modal dan Kinerja Keuangan. Jurnal Manajemen \& Bisnis, 9(1). 